\title{
Effects of Replacing Corn with Hydroponically Sprouted Barley on the Growth Performance and Blood Metabolite Status of Holstein Dairy Heifers
}

\author{
Tae-Il Kim ${ }^{1,+}$, Dong-Hyun Lim ${ }^{1,+}{ }^{+}$, Hyun-Jeong Lee ${ }^{1}$, Seong-Min Park ${ }^{1}$, Yoon-Jeong Kim ${ }^{2}$, \\ Hee-Chul Choi ${ }^{1}$, Jong-Ho Park ${ }^{3}$, Sam-Churl Kim ${ }^{4} \oplus$, Kwang-Seok Ki ${ }^{1}$ and \\ Vijayakumar Mayakrishnan ${ }^{1, *(D)}$ \\ 1 Dairy Science Division, National Institute of Animal Science, Rural Development Administration, \\ Chungcheongnam-do, Cheonan 31000, Korea; kimti@korea.kr (T.-I.K.); idh1974@korea.kr (D.-H.L.); \\ hyunj68@korea.kr (H.-J.L.); bek9love@korea.kr (S.-M.P.); rooster@korea.kr (H.-C.C.); \\ kiks386@korea.kr (K.-S.K.) \\ 2 Gffa, Inc., 119 CheonggyesanRo, SeochoGu, Seoul 06802, Korea; ceo@gffa.co.kr \\ 3 Crop Breeding Division, National Institute of Crop Science, Rural Development Administration, \\ Wanju-gun, Jeolabuk-do 55365, Korea; ark0104@korea.kr \\ 4 Division of Applied Life Science (BK21 Four, Institute of Agriculture and Life Science), \\ Gyeongsang National University, Jinju, Gyeongsangnam-do 52828, Korea; kimsc@gnu.ac.kr \\ * Correspondence: marulbiochem@korea.kr; Tel.: +82-41-580-3401; Fax: +82-41-580-3419 \\ + These authors contributed equally to this work.
}

Received: 29 September 2020; Accepted: 21 October 2020; Published: 23 October 2020 updates

\begin{abstract}
This study aimed to determine the effects of replacing corn with hydroponically sprouted barley (HSB) in Holstein heifer feed on growth performance and blood metabolites. For this purpose, the barley was prepared with hydroponic sprouting under optimized conditions, and its chemical composition was analyzed on a dry matter (DM) basis. A total of 30 Holstein heifers that were 7 months old with an average body weight of $212.60 \pm 55.00 \mathrm{~kg}$ were used in a completely randomized design comprising 10 repetitions and three groups over a period of 11 months. Dietary treatments included control (CON), basal diet (corn meal-based diets), and trail diets, in which 10\% and 30\% HSB gradually replaced corn meal. The growth performance and biochemical indices were analyzed every month. Results showed that the HSB diet increased chemical compositions compared with the control diets on a DM basis. In addition, diets with up to 30\% HSB did not show any negative effects on the growth performance (body weight, height at withers, and height at rump) or selected blood metabolites of heifers compared with the CON diet. In conclusion, the use of HSB instead of corn meal did not lead to any adverse effects on growth performance or biochemical indices; therefore, HSB can be used as an alternative dietary source for raising Holstein heifers.
\end{abstract}

Keywords: hydroponic; barley; corn; body weight; blood metabolites; rectal temperature

\section{Introduction}

In animal agriculture production, feed is considered the most essential and expensive element. Thus, there is a need to investigate all possible biological feed resources for livestock production, including agricultural byproducts, forages, and weeds [1]. In recent years, hydroponic fodder production companies have been announced extensively to produce feed for ruminants all over the world, which has renewed the interest of livestock farmers and researchers as well [2,3]. Hydroponic fodder is produced from grains that are germinated and grown under optimized conditions in greenhouses within a short time period [4]. The utilization of sprouted fodder is not a new idea. 
Since the 1600s, small sprouted grains have been used for fodder preparation [5]. Among the cereals, barley is the most important ancient cereal crop produced globally. The most important features of hydroponic fodder production are that $1 \mathrm{~kg}$ of barley grains can produce from 7 to $10 \mathrm{~kg}$ of green fodder within a week under well-controlled conditions [6]. Hydroponically produced green forage sprouts are highly palatable, have a height range between 15 and $20 \mathrm{~cm}$, and are produced without the soil germination of cereal grains, such as barley and maize, using water and nutrient mineral solutions [7]. Freshly prepared hydroponically sprouted barley can be an important source of overall rations, which has been demonstrated to advance animal health, diminish heat stress, and increase productivity [8]. Germination activities in seeds involve many modifications, such as seed proteins being converted to essential amino acids, carbohydrates converted to sugars, and fats converted to essential fatty acids, and these increased activities lead to higher enzyme levels [3]. Hydroponically germinated barley is characterized by its level of crude protein, crude fiber, ash, minerals, and vitamins [9]. Furthermore, germination reduces phytic acid levels in seeds, which produces an insoluble complex, and minerals as well enzymes are produced during sprouting that can remove other anti-nutritional elements [10]. The digestive enzymes in sprouts act as biological catalysts in the digestion of carbohydrates, proteins, and fats. Furthermore, sprouting and germination processes neutralize the inhibitors that improve beneficial digestive enzymes [11]. During barley germination, the alkaloid hordenine is formed, which exhibits epinephrine-like activity, stimulating the heart, constricting vessels, and relaxing constricted bronchioles. Hordenine and other alkaloids are closely associated with palatability, intake, and weight gain in animals [12].

The use of methodology and engineering in sprouting makes it economically competitive with other feed choices. This technique may be particularly important for farmers who have little or no land for forage production [8]. Furthermore, this process typically requires a specific, controlled amount of water and nutrient mineral solution to avoid expensive commercial nutrition solutions that can minimize expected profits. An earlier study reported that hydroponic fodder germinated successfully with tap water without any supplementation of nutrients, but its nutritional content was affected. In addition, nitrogen is essential for the production of leafy and green plants and can be extracted from the atmosphere by the plant root or the stoma of the leaves and stems [13]. On the other hand, dairy heifers may represent excessive resource costs for feed, housing, and labor, yet return no money to the dairy farm until they calve or are sold, and feed cost may represent up to $60 \%$ of heifers' raising expenses and $12 \%$ of total dairy farm expenses. Few studies have been conducted to investigate the effect of the partial replacement of corn by HSB for dairy heifers. Thus, alternative feeds with a lower price must be produced. In this study, we aim to determine the effect of hydroponically sprouted barley (HSB) on Holstein dairy heifer growth performance and biochemical metabolites. This study was performed by comparing the value of feed with various concentrations of sprouted barley, with and without concentrates.

\section{Materials and Methods}

\subsection{Production of Hydroponically Sprouted Barley Fodder}

The sprouted barley was prepared by Gffa, Inc. (Seoul, Korea), following the method of Gebremedhin [6] using a hydroponic sprouting unit with a size of $4.0 \times 6.0 \times 2.3 \mathrm{~m}$ as length $\mathrm{x}$ width $\mathrm{x}$ height. A semi-automatic irrigation sprayer was used to irrigate the barley grains (Keunalbori1ho) with nutrient-added tap water. The greenhouse temperature was maintained at $16-23^{\circ} \mathrm{C}$, the humidity was $40-80 \%$, and the water temperature was $16-23^{\circ} \mathrm{C}$. To promote leaf growth, fluorescent lighting pipes and irrigation equipment were arranged vertically on the walls. Barley grains were obtained from Nerundul Farming Association Corp, Gimje-si, Korea. To prevent fungal contamination, the purchased barley grain was first washed with fresh water and then soaked with $0.1 \%$ hypochlorite for $24 \mathrm{~h}$. Afterward, the cleaned barley grains were transferred to a plastic bowl and covered with a wet cloth for another $24 \mathrm{~h}$ to induce germination. They were then spread on a tray at a rate of 300 
$\mathrm{g}$ with a thickness of $1.5-2.0 \mathrm{~cm}$. To irrigate the barley grains, on the first day, tap water (included nutrients) was provided at a flow rate of $0.47 / \mathrm{min}$, and from the second day, the tap water was adjusted according to the water requirements. The total production of 6 days of hydroponically sprouted barley fodder was recorded. The samples were dried using an oven (Forced Convection Oven, Jeiotech, Daejeon, Korea (KOR)) at $63{ }^{\circ} \mathrm{C}$ for $72 \mathrm{~h}$, ground using a cyclone mill (Foss Tecator Cyclotec 1093, Foss, Hillerød, Denmark) to pass through a 1-mm mesh screen sieve, and stored prior to the analysis of their chemical compositions.

\subsection{Analysis of Chemical Compositions}

The chemical compositions of the samples were analyzed based on the National Research Council guidelines [14]. The content of dry matter (DM), crude protein, crude fat, crude fiber, and crude ash, were determined as described in [15]. The acid detergent fiber (ADF) and neutral detergent fiber (NDF) without the use of sodium sulfite or lignin were analyzed by the method described in [16].

\subsection{Animals, Management, Feeding, and Experimental Design}

The study was conducted at the National Institute of Animal Science, Cheonan, Korea. Holstein heifers were selected for this study, and the experiment was carried out from June 2019 to April 2020. At the beginning of the study, the Holstein heifers $(n=30)$ were $7 \pm 0.2$ months of age and had a body weight of $210.98 \pm 2.10 \mathrm{~kg}$. The heifers were housed in one section of a free-stall barn, which had metal roofs over the free stalls and feeding area but was open between the roofs. Heifers were provided with supplemental cooling by fans. All heifers were maintained according to standard guidelines, and the experimental procedures of this research were approved by the Institutional Animal Care and Use Committee, protocol number (IACUC No: 2018-303) of the National Institute of Animal Science, Jeonju, Korea. The heifers were divided into three groups (with 10 animals in each group), and the treatment included (1) a control diet with corn meal as the major concentrate ingredients (CON), (2) $10 \%$ (DM basis) hydroponically sprouted barley replacing the corn meal, and (3) 30\% (DM basis) hydroponically sprouted barley replacing the corn meal. All the heifers were fed a total mixed ration (TMR, $\mathrm{NE}_{\mathrm{L}}$ $1.7 \mathrm{Mcal} / \mathrm{kg}$, TDN $72.2 \%$ ) twice daily at 09:00 and 17:00 $\mathrm{h}$, water was provided ad libitum, and the TMR was formulated to meet the heifers' requirements [14] for energy, protein, minerals, and vitamins. The feed ingredients used in the treatment diets, and the nutrient compositions of the ration based on the realized TMR are presented in Table 1.

\subsection{Growth Performance and Biochemical Indices Analysis}

For growth performance measurements, each heifer was weighed monthly, from 7 to 17 months of age. The measurements of height at the withers and rump, in addition to weight, were taken as the animal stood naturally and continued every month from age 7 to 17 months. The height of the animal was measured as the vertical distance from the top of the withers to the ground. A blood sample was collected via jugular venipuncture from each heifer once a month, from age 12 to 17 months, using sterile vacutainer tubes. The collected blood samples were centrifuged at $1000 \times \mathrm{g}$ for $15 \mathrm{~min}$ at $4{ }^{\circ} \mathrm{C}$. The serum sample was collected and stored at $-20^{\circ} \mathrm{C}$ for further analysis. Serum samples were used to analyze the metabolic status (Wako Chemicals, Neuss, Germany) by using a blood auto-analyzer (Hitachi, 7180, Japan). The biochemical indices of total protein, albumin, urea nitrogen (UN), creatine kinase (CK), creatinine, calcium, phosphorous, magnesium, glucose, non-essential fatty acid (NEFA), serum glutamate oxaloacetate transaminase (SGOT), serum glutamate pyruvate transaminase (SGPT), lactate dehydrogenase (LDH), total cholesterol, and triglycerides (TG) level were analyzed with a Clinical Analyzer (Hitachi 7180, Japan). The serum cortisol, progesterone, and estrogen concentrations were measured using a commercial ELISA kit (Wuhan Abebio Science, Wuhan, China) according to the manufacturer's instructions. 
Table 1. Feed ingredients and chemical composition of the control (CON) and hydroponically sprouted barley (HSB) fed to growing Holstein heifers for 11 months.

\begin{tabular}{|c|c|c|c|}
\hline Item & $\mathrm{CON}$ & HSB $(10 \%)$ & HSB $(30 \%)$ \\
\hline \multicolumn{4}{|l|}{$\begin{array}{c}\text { Ingredient } \\
\text { compositions }(\% \mathrm{DM})\end{array}$} \\
\hline Corn & 15.0 & 13.5 & 10.5 \\
\hline Cotton seed & 3.0 & 3.0 & 3.0 \\
\hline Corn gluten feed & 15.2 & 27.5 & 27.6 \\
\hline Cotton seed hull pellet & 19.2 & 11.1 & 5.0 \\
\hline Molasses & 3.0 & 3.0 & 3.0 \\
\hline Soybean meal & 14.8 & 10.6 & 7.6 \\
\hline Brewer's spent grain & 10.0 & 10 & 10 \\
\hline Alfalfa hay & 8.0 & 8.0 & 8.0 \\
\hline Klein grass hay & 3.0 & 3.0 & 3.0 \\
\hline Timothy hay & 3.0 & 3.0 & 3.0 \\
\hline Oat hay & 3.0 & 3.0 & 3.0 \\
\hline Limestone & 2.0 & 2.0 & 2.0 \\
\hline Salt & 0.3 & 0.3 & 0.3 \\
\hline Vitamins \& Minerals mix & 0.5 & 0.5 & 0.5 \\
\hline HSB & & 1.5 & 4.5 \\
\hline Total & 100 & 100 & 100 \\
\hline \multicolumn{4}{|l|}{$\begin{array}{c}\text { Chemical compositions } \\
\text { (\%DM) }\end{array}$} \\
\hline DM (\% as feed $)$ & $79.11^{\mathrm{a}}$ & $70.01^{b}$ & $70.62^{b}$ \\
\hline Moisture & $20.89^{b}$ & $20.99^{b}$ & $29.38^{\text {a }}$ \\
\hline Crude protein & $19.14^{\mathrm{ab}}$ & $18.27^{\mathrm{b}}$ & $20.25^{\mathrm{a}}$ \\
\hline Crude fat & $5.23^{\mathrm{ns}}$ & $5.82^{\mathrm{ns}}$ & $5.33^{\mathrm{ns}}$ \\
\hline Crude fiber & $14.85^{\mathrm{a}}$ & $15.62^{\mathrm{a}}$ & $12.16^{\mathrm{b}}$ \\
\hline Ash & $8.34^{\mathrm{a}}$ & $7.65^{\mathrm{a}}$ & $6.11^{\mathrm{b}}$ \\
\hline ADF & $19.34^{\mathrm{a}}$ & $19.36^{\mathrm{a}}$ & $14.73^{\mathrm{b}}$ \\
\hline NDF & $37.53^{\mathrm{a}}$ & $39.56^{\mathrm{a}}$ & $32.39^{b}$ \\
\hline Energy (Mcal/kg) & $3423.00^{\mathrm{a}}$ & $3404.33^{\mathrm{a}}$ & $3122.67^{b}$ \\
\hline Lignin & $3.17^{\mathrm{ns}}$ & $3.05^{\mathrm{ns}}$ & $2.18^{\mathrm{ns}}$ \\
\hline B-carotene $(\mu \mathrm{g} / 100 \mathrm{~g})$ & $366.14^{\mathrm{ns}}$ & $397.26^{\mathrm{ns}}$ & $400.83^{\mathrm{ns}}$ \\
\hline \multicolumn{4}{|c|}{ Feed cost (Korean won/kg DM) } \\
\hline Corn & 271 & \multirow{2}{*}{\multicolumn{2}{|c|}{583}} \\
\hline HSB & - & & \\
\hline
\end{tabular}

Values are expressed as the mean \pm SEM of the 3 replicates in each group. ${ }^{\mathrm{a}, \mathrm{b}}$ and ${ }^{\mathrm{ns}}$ denote comparisons made between columns $(p<0.05)$.

\subsection{Statistical Analysis}

All data were subjected to statistical analysis in a randomized block design using the general least-squares (PROC GLM) procedures of the SAS program (SAS Institute Inc, Cary, NC, USA). The values were indicated as least-squares means and the standard error of the mean. The differences between the means of the treatment groups were determined using Duncan's multiple range test with a $p<0.05$ representing statistical significance.

\section{Results}

\subsection{Nutritional Compositions of HSB}

The chemical composition of the hydroponically sprouted barley and CON diet on a DM basis are shown in Table 1. The feed with corn replaced by 30\% HSB had higher crude protein (20.25), and lower crude fiber (12.16), ash (6.11), ADF (14.73), and NDF (32.39) than the control (CON) diet on a DM basis. Together, corn replaced by $15 \%$ HSB showed similar chemical compositions to the CON diet. However, 
no significant difference was noted for crude fat, lignin, and $\beta$ - carotene content between the HSB (15\% and $30 \%$ replacement) and CON diets on a DM basis.

\subsection{Effect of HSB on Growth Performance in Holstein Dairy Heifers}

The effect of partially replacing corn with HSB in Holstein heifer feed on the heifers' live body weight is presented in Figure 1. The results of the present study showed that there was no significant difference noted in the live body weight of heifers fed with a diet having corn meal replaced with $10 \%$ and 30\% HSB compared with the CON diet. Similarly, the values for height at withers and height at rump were not changed when the heifers were fed with $10 \%$ and $30 \%$ HSB compared with the CON $\operatorname{diet}(p<0.05)$, as shown in Figure $2 \mathrm{a}$ and $\mathrm{b}$, respectively. The activity volume was similar in heifers fed with $10 \%$ and $30 \%$ HSB and the CON diet $(p<0.05)$. However, a higher rectal temperature was observed in the heifers supplemented with the 30\% HSB diet than those fed with the $10 \%$ HSB and $\mathrm{CON}$ diets, although the increased rectal temperature value was within the normal range (Table 2).

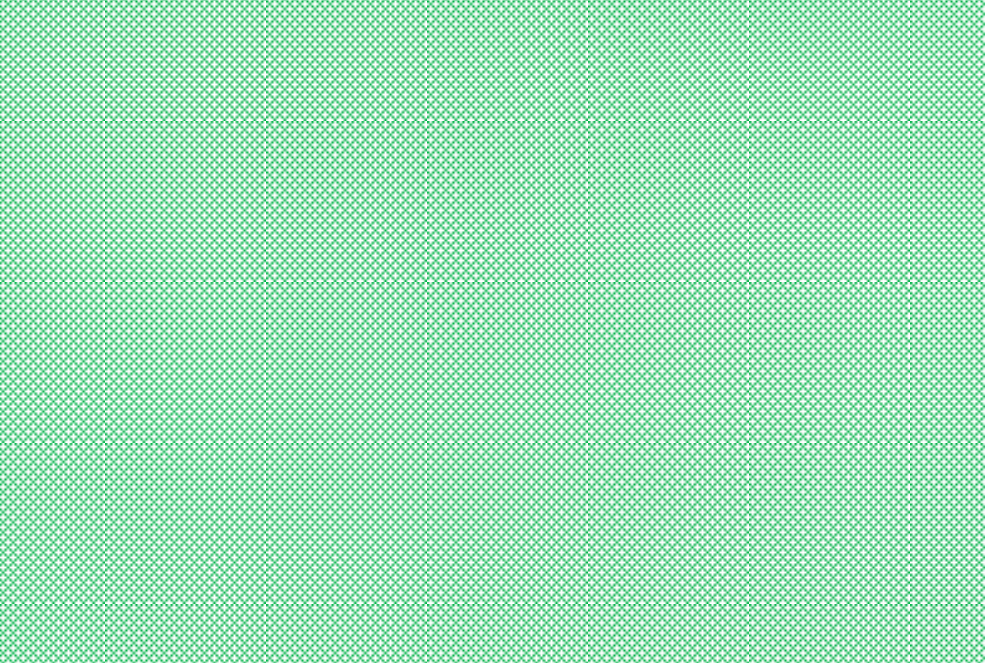

Figure 1. Effect of feeding hydroponically sprouted barley on body weight changes in Holstein heifers.

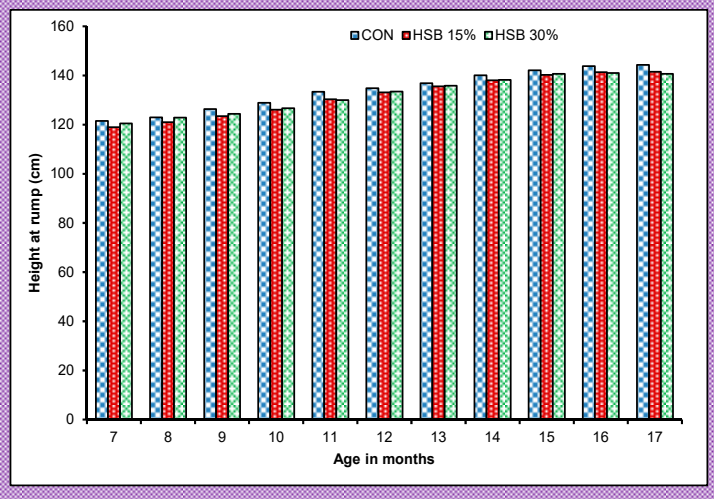

(a)

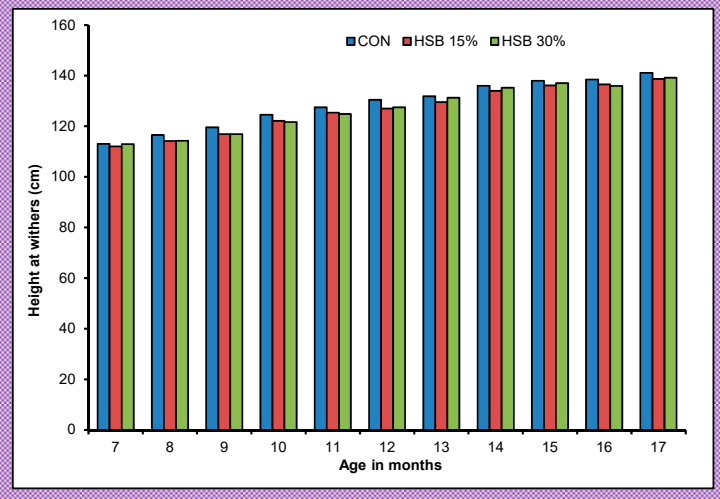

(b)

Figure 2. Effect of feeding hydroponically sprouted barley on height at withers (a) and height at rump (b) of Holstein heifers. 
Table 2. Effects of feeding hydroponically sprouted barley on behavior activity volume and rectal temperature in Holstein heifers $(\mathrm{n}=10)$.

\begin{tabular}{|c|c|c|c|c|}
\hline Months & & $\mathrm{CON}$ & HSB (10\%) & HSB (30\%) \\
\hline \multirow{2}{*}{13} & Activity volume (Unit) & $6247.40 \pm 376.80^{\mathrm{ns}}$ & $6265.50 \pm 394.40^{\mathrm{ns}}$ & $6155.27 \pm 347.45^{\mathrm{a}}$ \\
\hline & $\mathrm{RT}\left({ }^{\circ} \mathrm{C}\right)$ & $38.55 \pm 0.03^{\mathrm{ns}}$ & $38.61 \pm 0.05^{\mathrm{ns}}$ & $38.84 \pm 0.04^{\mathrm{ns}}$ \\
\hline \multirow{2}{*}{14} & Activity volume (Unit) & $6101.91 \pm 136.01^{b}$ & $6747.82 \pm 196.86^{\mathrm{a}}$ & $6232.05 \pm 150.11^{a}$ \\
\hline & $\mathrm{RT}\left({ }^{\circ} \mathrm{C}\right)$ & $38.57 \pm 0.01^{\mathrm{ns}}$ & $38.55 \pm 0.01^{\mathrm{ns}}$ & $38.81 \pm 0.01^{\mathrm{ns}}$ \\
\hline \multirow{2}{*}{15} & Activity volume (Unit) & $6232.51 \pm 191.65^{\mathrm{ns}}$ & $6346.50 \pm 220.05^{\mathrm{ns}}$ & $5959.98 \pm 182.86^{\mathrm{ns}}$ \\
\hline & $\mathrm{RT}\left({ }^{\circ} \mathrm{C}\right)$ & $38.33 \pm 0.03^{\mathrm{ns}}$ & $38.50 \pm 0.03^{\mathrm{ns}}$ & $38.67 \pm 0.02 \mathrm{~ns}$ \\
\hline \multirow{2}{*}{16} & Activity volume (Unit) & $5992.65 \pm 158.90^{\mathrm{ns}}$ & $6374.03 \pm 160.91^{\mathrm{ns}}$ & $5851.01 \pm 151.09^{a}$ \\
\hline & $\mathrm{RT}\left({ }^{\circ} \mathrm{C}\right)$ & $38.52 \pm 0.03^{c}$ & $38.65 \pm 0.04^{b}$ & $38.85 \pm 0.03^{\mathrm{a}}$ \\
\hline \multirow{2}{*}{17} & Activity volume (Unit) & $5467.90 \pm 169.91^{\mathrm{ns}}$ & $6276.82 \pm 234.85^{\mathrm{ns}}$ & $5427.25 \pm 155.12^{\mathrm{ns}}$ \\
\hline & $\mathrm{RT}\left({ }^{\circ} \mathrm{C}\right)$ & $38.47 \pm 0.03^{\mathrm{ns}}$ & $38.60 \pm 0.02^{n s}$ & $38.76 \pm 0.02^{\mathrm{ns}}$ \\
\hline
\end{tabular}

Values are expressed as the mean \pm SEM of 10 dairy heifers in each group. ${ }^{a, b, c}$ and ${ }^{\text {ns }}$ denote comparisons made between columns $(p<0.05)$.

\subsection{Effect of HSB on Blood Metabolites in Holstein Dairy Heifers}

The data concerning the blood metabolites in Holstein heifers fed the CON and HSB diets are presented in Supplementary Tables S1-S5. During the study period, there were no significant changes observed in the selected blood metabolites in Holstein heifers fed a diet supplemented with $10 \%$ and $30 \%$ HSB as compared with those fed the CON diet $(p<0.05)$. However, blood glucose levels were slightly increased during the seventeenth month in heifers fed the HSB and CON diets $(p<0.05)$.

\section{Discussion}

The cost involved in raising heifers is an important issue for dairy farmers. Additional animals typically account for $15-20 \%$ of milk production costs. The replacement of heifers ranks as the second or third largest component of production costs after feed and possibly labor on animal agriculture production. The costs can vary from farm to farm, depending on individual management strategies. The aim of raising heifers should be to minimize costs while still maximizing the returns on the costs incurred. Therefore, the objective of a dairy replacement heifer management program depends on the successful rearing of heifers to minimize costs without compromising future lactation performance. Corn is a primary energy source that is mainly used as an ingredient in preparing feed for ruminants in Korea. However, corns are generally imported from other countries, and the cost of feed is high. Therefore, farmers and researchers have placed more attention on searching for an alternative to corn meal. Dietary energy, DM intake, body weight, and weight gain are closely associated with growth performance in ruminants [17]. Therefore, in this study, we evaluated the effects of HSB on growth performance and biochemical metabolites in Holstein heifers in Korea. The results of the present study revealed that there were no significant changes in the live body weight of heifers fed with a $10 \%$ and 30\% HSB diet when compared with the CON diet. Moreover, the average daily weight gain was determined from body weight measured monthly, and no significant difference was noted between the 10\% and 30\% HSB diet-supplemented heifers and the CON-supplemented heifers. Therefore, the study findings confirmed that HSB could be a substitute for corn meal in feed for ruminants in Korea. The regulation of feed intake and energy balance are influenced by many factors, including age, initial live weight, nutrition, breed features, and management program [18], and this feed intake and energy balance is predicted for metabolic, digestive tract, and external factors [19]. Limited research has been published to evaluate the feed value of sprouting barley. Early study results have shown that a 10-day sprouted barley diet in pigs induced lower weight gain as compared with ground maize, but in beef cattle, sprouted barley green fodder showed a $200 \mathrm{~g}$ higher daily gain as compared with a maize control diet [20]. 
Biochemical indices are key markers of general health and vitality and may indicate the action of certain tissue, organ, and nutrient status. The increased concentration of blood glucose represented a high level of absorption of glucose due to the energy-yielding substrate and glucose consumption [21,22]. Our study finding also showed an increased concentration of glucose at the seventeenth month for heifers fed with $30 \%$ HSB. The increased blood glucose concentration was observed after the replacement of corn with HSB. Under normal physiological circumstances, blood glucose plays a key function in energy storage in tissues, organs, and the central nervous system, and it provides a suitable physiological guide for overall energy metabolism. The replacement of corn with HSB did not alter the total protein, albumin, BUN, CK, or creatinine concentration in Holstein heifers as compared with the CON-fed heifers. BUN is an end product of protein and amino acid catabolism in the body; it is negatively associated with nitrogen deposition and protein/amino acid utilization. When amino acids are imbalanced in the body, or when there is poor utilization of protein in the body, the BUN concentration increases [23]. Blood metabolites such as total cholesterol, TG, oxalo-acetate transaminase, and pyruvate transaminase, as well as total protein and LDH concentrations can be used as predictors of fat and protein metabolism and of liver function. In this experiment, the above parameters were not significantly altered when heifers were fed the $10 \%$ and $30 \%$ HSB diet as compared with the CON diet, indicating that the replacement of corn with HSB in the diet of growing Holstein heifers did not adversely affect their carbohydrate, lipid, and protein metabolism.

Despite increasing livestock production, feed management practice is considered an important factor in animal agriculture. Cortisol is an important indicator that is used to determine the stress condition of an animal. Increased levels of cortisol in the blood indicate that an animal may be under stress, which leads to a decrease in reproduction. Therefore, cortisol levels are measured to evaluate whether an animal is experiencing stress conditions. In this study, we determined, every month for the entire study period, the blood cortisol level of heifers fed the $10 \%$ and $30 \%$ HSB diets and the CON diet. Our results showed that the $10 \%$ and 30\% HSB diet did not negatively affect the cortisol levels when compared with the CON diet. Feed additives can indirectly alter the cortisol level in blood serum, but some studies only show that feeding may change the cortisol level in blood serum. Progesterone and estrogen are considered reproductive markers. Butler and Smith [24] demonstrated a strong relationship between negative energy balance and conception rate. In this study, we evaluated the level of reproductive hormones in blood, and these hormone levels were not significantly different between heifers fed the 10\% and 30\% HSB diets and the CON diet, which reflected the reproductive performance of the heifers. From these study findings, we confirmed an improved energy balance when heifers were fed the $10 \%$ and $30 \%$ HSB diet. These hormones increase cholesterol, lipoprotein, HDL, and sodium excretion. Further, these hormones are closely associated with the measurement of DM intake, average daily gain, and feed efficiency in heifers.

\section{Conclusions}

The findings of the present pilot study demonstrated that the partial replacement of corn with HSB had no adverse effects on live body weight, height at withers, or height at rump in Holstein heifers. Similarly, the substitution of corn with HSB had no negative effect on blood metabolites in Holstein heifers, and the feed cost of HSB was lower than corn. Thus, it is recommended to partially replace corn with HSB with the concentrate mixture to obtain optimal DM intake as well as high animal performance. However, further study is required in future concerning whether a higher level of substitution of corn meal with HSB has any adverse effect on Holstein dairy cattle growth performance and milk production.

Supplementary Materials: The following are available online at http://www.mdpi.com/2076-3417/10/21/7442/s1.

Author Contributions: T.-I.K., D.-H.L., K.-S.K., and V.M. conceived and designed the experiments; T.-I.K., funding acquisition; T.-I.K., D.-H.L., V.M., H.-J.L., S.-M.P., Y.-J.K., H.-C.C., J.-H.P., and S.-C.K. performed most of the experiments; V.M. wrote the manuscript, and K.S.K. supervised and provided many helpful suggestions regarding the study and manuscript writing. All authors have read and agreed to the published version of the manuscript. 
Funding: This study was supported by the Cooperative Research Program for Agricultural Science and Technology Development (Project Title: Effects of sprouted barley diet on growth performance of Holstein cows in a growing period; Project No: PJ013869032020) of the Rural Development Administration of the Republic of Korea.

Acknowledgments: The authors are grateful to the Rural Development Administration for providing the Postdoctoral Research Associate Fellowship of the National Institute of Animal Science of Korea.

Conflicts of Interest: The authors declare no conflict of interest.

\section{References}

1. Safwat, M.S.; Sarmiento-Franco, L.; Santos-Ricalde, R.H. Rabbit production using local resources as feedstuffs in the tropics. Trop. Subtrop. Agroecosyst. 2014, 17, 161-171.

2. Lisa, B. Hydroponic Fodder in an Organic Pastured Poultry System. Can Feed Costs be Reduced? Project report. 2014. Available online: http://mysare.sare.org/sare_project/fnc13-02/?page=final\&view=print. (accessed on 12 November 2014).

3. Prakash, D.S. Effect of Replacement of Concentrate Mixture by Maize Hydroponic Fodder on Performance of Goat. Master's Thesis, Maharashtra Animal and Fishery, Sciences University, Nagpur, India, April 2017.

4. Sneath, R.; Felicity, M. Review of Hydroponic Fodder Production for Beef Cattle; Department of Primary Industries: Brisbane, Australia, 2003; Volume 84, p. 54.

5. Pedretti, J. Sprouted Barley fodder-A revolution in Animal feed? Org. Broadcas. 2013, 21, 1-2.

6. Gebremedhin, W.K. Nutritional benefit and economic value of feeding hydroponically grown maize and barley fodder for Konkan Kanyal goats. J. Agric. Vet. Sci. 2015, 8, 24-30.

7. Cortazzo, A.S. Hydrophonic Green Forage Technical Manual; Food and Agriculture Organization of the United Nations: Santiago de Chile, Chile, 2001.

8. Mohsen, M.K.; Abdel-Raouf, E.M.; Gaafar, H.; Yousif, A.M. Nutritional evaluation of sprouted barley grains on agricultural by-products on performance of growing New Zealand white rabbits. World Rural Obs. 2015, 7, 96-107.

9. Morgan, J.; Hunter, R.R.; O'Haire, R. Limiting factors in hydroponic barley grass production. In Proceedings of the 8th International Congress on Soilless Culture, Hunter's Rest, South Africa, 2-9 October 1993; pp. 241-261.

10. Girma, F.; Gebremariam, B. Review on hydroponic feed value to livestock production. J. Sci. Innov. Res. 2018, 7, 106-109.

11. Smith, T.A. Phenethylamine and related compounds in plants. Phytochemistry 1977, 16, 9-18. [CrossRef]

12. Marten, G.C.; Jordan, R.M.; Hovin, A.W. Biological Significance of Reed Canarygrass Alkaloids and Associated Palatability Variation to Grazing Sheep and Cattle1. Agron. J. 1976, 68, 909-914. [CrossRef]

13. Yang, H.; Li, J.; Yang, J.; Wang, H.; Zou, J.; He, J. Effects of Nitrogen Application Rate and Leaf Age on the Distribution Pattern of Leaf SPAD Readings in the Rice Canopy. PLoS ONE 2014, 9, e88421. [CrossRef] [PubMed]

14. NRC, National Research Council. Nutrient Requirements of Dairy Cattle, 7th ed.; The National Academies Press: Washington, DC, USA, 2001.

15. AOAC International. Official Methods of Analysis of AOAC International; AOAC International: Washington, DC, USA, 2005.

16. Van Soest, P.J.; Robertson, J.B.; Lewis, B.A. Methods for Dietary Fiber, Neutral Detergent Fiber, and Nonstarch Polysaccharides in Relation to Animal Nutrition. J. Dairy Sci. 1991, 74, 3583-3597. [CrossRef]

17. Midelet, G.; Carpentier, B. Transfer of microorganisms, including Listeria monocytogenes, from various materials to beef. Appl. Environ. Microbiol. 2002, 68, 4015-4024. [CrossRef] [PubMed]

18. Berry, B.A.; Krehbiel, C.R.; Confer, A.W.; Gill, D.R.; Smith, R.A.; Montelongo, M. Effects of dietary energy and starch concentrations for newly received feedlot calves: I. Growth performance and health. J. Anim. Sci. 2004, 82, 837-844. [CrossRef] [PubMed]

19. Asséré, A.; Oulahal, N.; Carpentier, B. Comparative evaluation of methods for counting surviving biofilm cells adhering to a polyvinyl chloride surface exposed to chlorine or drying. J. Appl. Microbiol. 2008, 104, 1692-1702. [CrossRef] [PubMed]

20. Leitch, I. Sprouted Fodder and Germinated Grain in Stock Feeding; Commonwealth Agricultural Bureaux: Wallingford, UK, 1939; Volume 11, pp. 3-63. 
21. Seal, C.J.; Parker, D.S. Effect of intraruminal propionic acid infusion on metabolism of mesenteric- and portal-drained viscera in growing steers fed a forage diet: I. Volatile fatty acids, glucose, and lactate. J. Anim. Sci. 1994, 72, 1325-1334. [CrossRef] [PubMed]

22. Balcells, J.; Seal, C.J.; Parker, D.S. Effect of intravenous glucose infusion on metabolism of portal-drained viscera in sheep fed a cereal/straw-based diet. J. Anim. Sci. 1995, 73, 2146-2155. [CrossRef] [PubMed]

23. Ponnampalam, E.N.; Egan, A.R.; Sinclair, A.J.; Leury, B.J. Feed intake, growth, plasma glucose and urea nitrogen concentration, and carcass traits of lambs fed isoenergetic amounts of canola meal, soybean meal, and fish meal with forage based diet. Small Rum. Res. 2005, 58, 245-252. [CrossRef]

24. Butler, W.R.; Smith, R.D. Interrelationships between energy balance and postpartum reproductive function in dairy cattle. J. Dairy Sci. 1989, 72, 767-783. [CrossRef]

Publisher's Note: MDPI stays neutral with regard to jurisdictional claims in published maps and institutional affiliations.

(C) 2020 by the authors. Licensee MDPI, Basel, Switzerland. This article is an open access article distributed under the terms and conditions of the Creative Commons Attribution (CC BY) license (http://creativecommons.org/licenses/by/4.0/). 